\title{
Acute and Subchronic Oral Toxicity Studies of Majun Brahmi and Itrifal Muqawwi Dimagh (Traditional Unani Formulations) in Rats
}

\author{
Monika Kumari, Amjad Saifi, Mahmood A. Khan, Vinod Kumar Arora', Yasmeen Shamsi², Sumita Halder ${ }^{3}$, \\ Rafat Sultana Ahmed \\ Departments of Biochemistry, 'Pathology and ${ }^{3}$ Pharmacology, University College of Medical Sciences and GTB Hospital (University of Delhi), Delhi, \\ 2Department of Moalajat, Faculty of Medicine (Unani), Jamia Hamdard, New Delhi, India
}

\begin{abstract}
Background: Majun Brahmi (MB) and Itrifal Muqawwi Dimagh (IMD) are polyherbal Unani formulations traditionally used for the treatment of mild cognitive impairment and memory enhancement. Although they are widely used, there is no particular scientific evidence regarding the toxicity of these medicines. Objective: The present study was undertaken to evaluate the safety of $\mathrm{MB}$ and IMD polyherbal Unani formulation. Materials and Methods: Wistar albino rats of both genders were treated with three doses of each drug - MB and IMD, i.e., 513.88, 1027.77, and $2055.54 \mathrm{mg} / \mathrm{kg}$ body weight (bwt) orally for 14 days for acute and 90 days for subchronic oral toxicity studies. At the end of the study, bwt gain, hematology, clinical biochemistry, and histopathological examination were performed. Although no significant changes in biochemical parameters occurred at the highest dose, mild damage to the liver, kidney, and spleen was observed. Results: At the lowest dose and at the dose of $1027.77 \mathrm{mg} / \mathrm{kg}$ bwt (therapeutic effective dose [TED]) of both the drugs, no abnormalities were observed in the biochemical and hematological parameters as well as histopathological findings. Conclusion: None of the rats exhibited apparent toxicity or mortality. The results of the present study provide evidence that both the formulations are not toxic at the TED dose and hence are clinically safe.
\end{abstract}

Key words: Acute toxicity studies, Itrifal Muqawwi Dimagh, Majun

Brahmi, Subchronic oral toxicity, Unani formulation

\section{SUMMARY}

- The present study was undertaken to evaluate the safety of the memory enhancing Unani formulation Majun Brahmi (MB) and Itrifal Muqawwi Dimagh (IMD)

- Wistar albino rats of both genders were treated with three doses of each drug - MB and IMD, i.e., 513.88, 1027.77, and $2055.54 \mathrm{mg} / \mathrm{kg}$ body weight (bwt) orally for 14 days for acute and 90 days for subchronic oral toxicity studies

- At the dose of $1027.77 \mathrm{mg} / \mathrm{kg}$ bwt (therapeutic effective dose [TED]) of both the drugs, no abnormalities were observed in the biochemical and hematological parameters as well as histopathological findings

- None of the rats exhibited mortality or apparent toxicity

- The present study provides evidence that both the formulations are nontoxic at the TED and hence safe for clinical use.

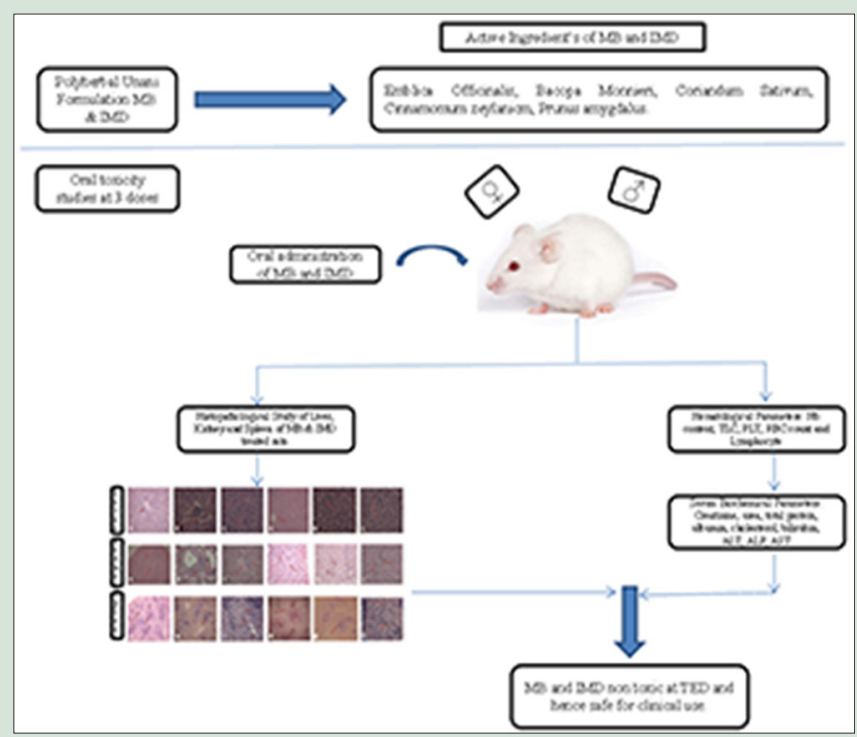

Abbreviations Used: MB: Majun Brahmi; BWT: Body weight; IMD: Itrifal Muqawwi Dimagh; TED: Therapeutic effective dose; HED: Human effective dose; RBC: Red blood cell; PLT: Platelet; TLC: White Blood Cell; SGOT: Serum glutamic oxaloacetic transaminase; SGPT: Serum glutamic pyruvic transaminase; ALP: Alakaline phosphatase; HDL: High-density lipoprotein

\section{Correspondence:}

Dr. Rafat Sultana Ahmed,

Department of Biochemistry, University

College of Medical Sciences and GTB Hospital

(University of Delhi), Dilshad Garden,

Delhi - 110 095, India.

E-mail: rafatnizam@rediffmail.com

DOI: 10.4103/pr.pr_93_19

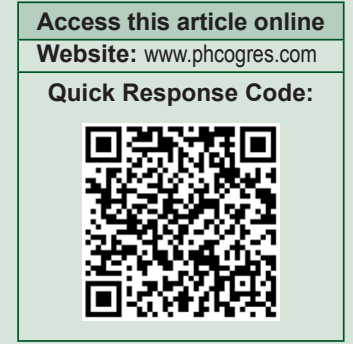

\section{INTRODUCTION}

Among all medicine systems practiced in India, Unani medicine has emerged as an extremely popular method of alternative treatment, during the past few decades. ${ }^{[1]}$ Unani medicines are being used since ancient times for the treatment of various ailments. In spite of the great advances observed in modern medicine in recent decades, Unani drugs still make an important contribution to the health-care system. The increased interest in using alternative medicines is solemn due to the fact that many allopathic medicines in use do have adverse reactions which quite often may be life-threatening. ${ }^{[2]}$ Hence, due to the limitations and risks in conventional therapy, many patients and practitioners are looking for alternative therapy. Herbs and herb-derived medicines in Ayurveda and Unani systems have been extensively used in the prevention and treatment of various diseases. Despite the widespread use of these drugs for the treatment of several ailments, little is known about their toxicity and safety. To have wide acceptance in the international community, Unani drugs need to satisfy various criteria such as safety, efficacy, and quality when tested through contemporary scientific tools. Therefore,

This is an open access journal, and articles are distributed under the terms of the Creative Commons Attribution-NonCommercial-ShareAlike 4.0 License, which allows others to remix, tweak, and build upon the work non-commercially, as long as appropriate credit is given and the new creations are licensed under the identical terms.

For reprints contact: reprints@medknow.com

Cite this article as: Kumari M, Saifi A, Khan MA, Arora VK, Shamsi Y, Halder S, Ahmed RS. Acute and subchronic oral toxicity studies of majun brahmi and itrifal muqawwi dimagh (traditional unani formulations) in rats. Phcog Res 2020;12:169-75. 
it is of utmost importance to validate traditional medicines for safe medicinal use. Although more than a thousand Unani drugs are available for clinical use, their use is relatively limited due to little knowledge regarding their safety/toxicity. Toxicology studies are therefore essential for the survival of formulations of herbal origin throughout the world. ${ }^{[3]}$ Safety evaluation studies endow necessary experimental data and information with respect to the scientific data and safety measures of a drug, thereby assuring their prescription by practitioners. If the safety/toxicity profile of such formulations is defined, they would have a better chance to compete with modern drugs and be accepted by the International Regulatory Agencies. ${ }^{[2]}$

Majun Brahmi (MB) and Itrifal Muqawwi Dimagh (IMD) are popular Unani formulations used for the treatment of cognitive impairment and memory enhancement. Many of their constituents [Tables 1 and 2] have their own pharmacological importance that diversifies their use in multiple therapeutic interventions. For example, a few reports indicate the memory-enhancing properties of individual components such as Emblica officinalis ${ }^{[4]}$ (Amla), Bacopa monnieri ${ }^{[5]}$ (Brahmi), Coriandrum sativum $^{[6]}$ (Coriander), Cinnamomum zeylanicm ${ }^{[7]}$ (Darchini), and Prunus amygdalus $^{[8]}$ (Almonds/Badam). Although MB and IMD are widely used in the Unani system of medicine as a brain tonic for enhancing memory and functions, there is no scientific documentation regarding safety, quality, toxicity, and efficacy of these two drugs in memory enhancement and improvement of cognitive functions and neuroprotection. The present study was designed to evaluate the safety of these two formulations using three different doses in both male and female experimental animals.

\section{MATERIALS AND METHODS}

\section{Study drugs and dosage}

The two Unani formulations, $\mathrm{MB}$ and $\mathrm{IMD}$, were procured from

Table 1: Ingredients of Majun Brahmi*

\begin{tabular}{lc}
\hline Each dose of $10 \mathrm{~g}$ contains & Weight \\
\hline Agar (Aquilaria agallocha Roxb) & $84 \mathrm{mg}$ \\
Badiyan (Foeniculum vulgafe Mill) & $168 \mathrm{mg}$ \\
Brahmi Booti (Bacopa monnieri Linn) & $837 \mathrm{mg}$ \\
Banslochan (Bambusa arundinaceae Willd) & $168 \mathrm{mg}$ \\
Ilaichi Khurd (Elettaria cardamomum Maton) & $84 \mathrm{mg}$ \\
Darchini (Cinnamomum zeylanicum Nees) & $42 \mathrm{mg}$ \\
Kishniz Khushk (Coriandrum sativum Linn) & $168 \mathrm{mg}$ \\
Mastagi Roomi (Pistacia lantiscus Linn) & $84 \mathrm{mg}$ \\
Maghz Badam Shirin (Prunus amygdalus Batsch) & $419 \mathrm{mg}$ \\
Maghz Pista (Pistacia vera Linn) & $419 \mathrm{mg}$ \\
Qiwam shaker (Sugar) & $7530 \mathrm{mg}$ \\
\hline
\end{tabular}

${ }^{*}$ National Formulary of the Unani Medicine, Department of AYUSH, Ministry of Health and Family Welfare, Government of India

Table 2: Ingredients of Itrifal Muqawwi Dimagh*

\begin{tabular}{lc}
\hline Each dose of 10 g contains & Weight \\
\hline Amla Khusk (Emblica officinalis Gaertn) & $145 \mathrm{mg}$ \\
Post Bahera (Terminalia bellerica Roxb) & $145 \mathrm{mg}$ \\
Post HalelaZard (Terminalia bellerica Roxb) & $290 \mathrm{mg}$ \\
Tukhm Khashkhash Safaid (Papaver Somniferum Linn) & $145 \mathrm{mg}$ \\
Gule Khatmi (Althaea Officinalis) (Linn) & $145 \mathrm{mg}$ \\
GuleSurkh (Rosa damascene Mill) & $145 \mathrm{mg}$ \\
Kishniz Khushk (Coriandrum sativum)(Linn) & $1305 \mathrm{mg}$ \\
Maghz Badam Shirin (Prunus amygdalus Batsch) & $145 \mathrm{mg}$ \\
Ghee (Clarified Butter) & $290 \mathrm{mg}$ \\
Shakar Safaid (Sugar) & $7235 \mathrm{mg}$ \\
Warq-e-Nuqra (Silver Leaves) & $14.5 \mathrm{mg}$ \\
\hline
\end{tabular}

${ }^{*}$ National Formulary of Unani Medicine, Department of AYUSH, Ministry of Health and Family Welfare, Government of India the Central Research Institute of Unani Medicine, Hyderabad, Telangana - 500 038. Their constituents are listed in Tables 1 and 2, respectively. ${ }^{[9]} \mathrm{MB}$ and IMD were weighed and mixed in distilled water to obtain a uniform suspension. The human effective dose (HED) of MB and IMD is $10 \mathrm{~g} /$ day. For rats, the therapeutic effective dose (TED) was calculated using the formula given below:

HED $(\mathrm{mg} / \mathrm{kg}$ body weight $[\mathrm{bwt}])=$ Animal dose $(\mathrm{mg} / \mathrm{kg}) \times$ Animal km/Human km

Where, $\mathrm{km}$ is the basal surface area. For rats, $\mathrm{km}$ is 6 , and for humans, ${ }^{[10]}$ it is 37 . For rats, the calculated TED of MB and IMD is $1027.77 \mathrm{mg} / \mathrm{kg}$ bwt. Other two doses used are half the TED (513.88 mg/kg bwt) and twice the TED (2055.54 $\mathrm{mg} / \mathrm{kg}$ bwt).

\section{Experimental animals}

Male and female Wistar strain albino rats (pathogen free) weighing $100-150 \mathrm{~g}$ were selected randomly from the central animal house facility of University College of Medical Sciences, Delhi, India. Rats were housed under similar conditions in clean well-ventilated polypropylene cages. All animals received humane care in compliance with the Committee for the Purpose of Control and Supervision of Experiments on Animals. They were allowed ad libitum drinking water and standard food pellets throughout the period of the study. Animals were maintained as per the conditions: light-dark cycle, $14-10 \mathrm{~h}$, the temperature was maintained at $22^{\circ} \mathrm{C} \pm 2^{\circ} \mathrm{C}$, and humidity was $40 \%-45 \%$. Rats were acclimatized to the experimental environment at least 1 week before the initiation of the experiment. Necessary approval for the study was obtained from the Institutional Animal Ethics Committee (IAEC) (Approval No: IAEC/2016-02 dated April 23, 2016).

\section{Animal groups and treatment Acute toxicity studies}

Acute toxicity studies were carried out according to the Organization for Economic Co-operation and Development (OECD) guidelines 420 and 423 adopted in December 17, 2001. Adult male rats were divided into eight groups (four groups of each treatment and five rats/group). Group 1 animals of each treatment group received $513.88 \mathrm{mg} / \mathrm{kg}$ bwt (0.5 times the TED), Group 2 animals received $1027.77 \mathrm{mg} / \mathrm{kg}$ bwt (equivalent to TED), and Group 3 animals received $2055.54 \mathrm{mg} / \mathrm{kg}$ bwt (twice the TED) of either MB or IMD orally once daily in the morning at 09:00 a.m. Adult female rats were also randomly divided into eight groups of five rats/group and were treated in a similar manner. Control rats of each treatment group of either sex received an equivalent amount of saline. Mortality and clinical signs were continuously observed after dosing at 0 hour and hourly up to $6 \mathrm{~h}$ on day 1 . From day 2 to day 14 , observation was restricted to once/day. After overnight fasting, animals were euthanized on day 15 . All internal organs were then subjected to gross histological examination.

\section{Subchronic toxicity studies}

Subchronic toxicity studies were also carried out according to the OECD guidelines. However, since no toxic effects and mortality were observed in the acute toxicity studies, instead of ten animals/group, five animals were used to minimize animal use. Adult male rats were divided randomly into eight groups (four groups for each treatment and five rats/group). Female rats were also divided into eight groups in a similar manner. The animals of different treatment groups of each sex were treated in a manner similar to that of the acute toxicity study. However, rather than 14 days, all animals were treated for 90 days. After overnight fasting, all the animals were anesthetized and blood samples were collected from retro-orbital plexus vein. The samples were processed for hematological and biochemical analyses. The hematological parameters such as 
hemoglobin $(\mathrm{Hb})$ content ${ }^{[11]}$ total leukocyte count (TLC), platelet (PLT), red blood cell (RBC) count, and lymphocyte were estimated in Mythic 18 Hematology Analyzer. The serum biochemical parameters such as creatinine, ${ }^{[12]}$ urea, ${ }^{[13]}$ total protein, ${ }^{[14]}$ albumin, ${ }^{[15]}$ cholesterol, ${ }^{[16]}$ and bilirubin $^{[17]}$ and enzymes such as aspartate transaminase (AST), ${ }^{[18]}$ alkaline phosphatase (ALP), ${ }^{[19]}$ and alanine transaminase (ALT) ${ }^{[18]}$ were estimated in a fully automated Clinical Chemistry Analyzer (DXC-600 Beckman Coulter, USA) using standard kits.

\section{Histopathology}

For subchronic toxicity studies, all animals were subjected to euthanasia by $\mathrm{CO}_{2}$ inhalation, and organs such as the liver, kidney, and spleen were collected. The tissues from these organs were numbered for identification and were transferred to tissue cassettes (SS), for fixation in 10\% formalin after $36-48 \mathrm{~h}$, the tissues were processed on an automatic tissue processor. Tissue sections were stained with eosin and were examined in a microscope using $\times 40$ and $\times 100$ objective to see the effects of the treatments on cell morphology and cell organelles.

\section{Statistical analysis}

The obtained raw data were subjected to statistical analysis using Graph Pad Prism Software, (2365 North side Dr. Suite 560 San Diego, CA 92108, USA). The data on bwt gain and hematological and biochemical parameters were analyzed statistically using Student's $t$-test and one-way analysis of variance using the GraphPad Prism version 5.0, followed by post hoc Tukey's test for different treatment groups comparing with vehicle control group data. All analyses and comparisons were evaluated at $95 \%$ level of confidence $(P<0.05)$.

\section{RESULTS}

\section{Acute toxicity (Majun Brahmi and Itrifal Muqawwi Dimagh)}

All animals were observed daily for any signs of toxicity or mortality. No sign of toxicity and animal death was observed in the wellness parameters during the 14-day observation period. Bwt was measured once a week. No adverse respiratory activity was observed in any of the treatment groups for both the drugs. The gross histological examination of all internal organs did not reveal any pathological changes at any dose.

\section{Subchronic toxicity of Majun Brahmi}

All animals were observed carefully every day to check for symptoms/ signs of any overt toxicity. Food and water consumption was not affected in all groups. The bwt changes were not statistically significant $(P<0.05)$ in the control as well as the drug-treated groups and were comparable in

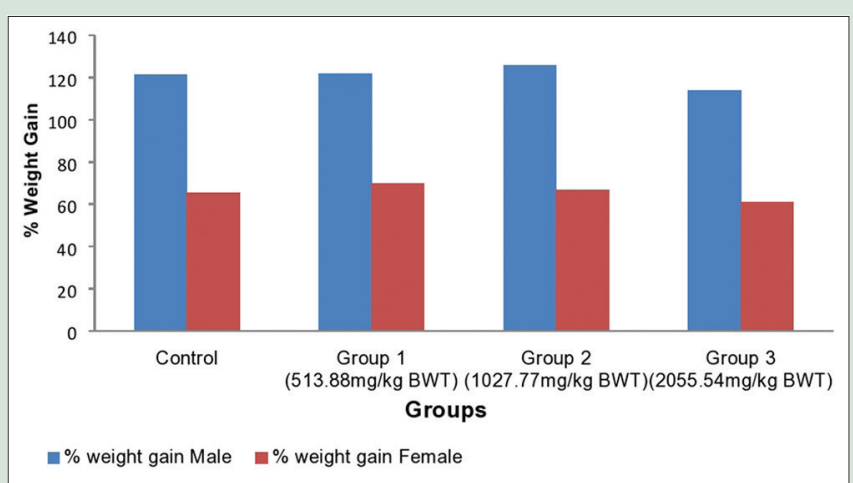

Figure 1: Body weight gain as a percentage in the control and MB-treated rats (Sub chronic toxicity study). MB: MajunBrahmi; BWT: body weight all the groups [Figure 1]. The hematological parameters of rats treated with $\mathrm{MB}$ are depicted in Table 3 . There was a significant $(P<0.05)$ rise in RBC levels in male rats at 0.5 TED (Group 1) and TED (Group 2) as compared to control male rats [Table 3]. There was a significant decrease in PLT count in male rats at all three doses, while in female rats, a significant increase at 0.5 TED and a significant decrease $(P<0.05)$ at TED and $2 \times$ TED level were observed $(P<0.05)$. Hb, lymphocyte, and TLC parameters were not affected significantly in both male and female rats in comparison to their respective control measurements in all three doses. There was a significant increase in ALP activity in female rats at 0.5 TED (Group 1) and serum glutamic pyruvic transaminase level in male rats at $2 \times$ TED as compared to controls $(P<0.05)$. All other biochemical parameters measured in treated rats were not significantly different from their respective controls $(P<0.05)$ [Table 4$]$. The histopathological examinations were performed on the liver, kidney, and spleen to assess whether any of the organs or tissues had been damaged or not. The liver of the control group had histologically normal structure for the central vein, parenchyma, and sinusoid. Moderate portal inflammation and inflammatory cell hyperplasia in the portal area were observed in TED-treated rats. The highest dose-treated rats showed microvesicular steatosis, fatty changes, and congestion in sinusoids [Figure 2]. Renal tissues of control rats showed normal glomeruli and normal tubules. At TED, tubular dilation and mild interstitial inflammation were observed. However, rats treated with the highest dose showed tubular atrophy with the tubular cast and focal area of inflammation [Figure 3]. Normal red and white pulp was observed in splenic tissues of control rats, while TED-treated rats showed mild congestion in red pulp, while mega karyocytes were observed in red pulp of rats treated with $2 \times$ TED [Figure 4].

\section{Subchronic toxicity study of Itrifal Muqawwi Dimagh}

No apparent clinical signs of toxicity were observed in the IMD-treated rats throughout the experimental period (90 days). Food and water consumption remained unaffected. The percent bwt gain was not significantly different $(P<0.05)$ in all the treated groups of both sexes [Figure 5], as compared to controls. The hematological parameters in rats treated with IMD are shown in Table 5. A significant increase in lymphocyte in female rats at $2 \times$ TED was observed. No significant changes were observed in $\mathrm{Hb}, \mathrm{TLC}, \mathrm{RBC}$, and PLT at all three doses in both male and female rats $(P<0.05)$. The levels of biochemical parameters of rats treated with IMD were not significantly different from the respective control groups $[P<0.05$, Table 6]. Gross histopathological examination of the liver, kidney, and spleen of rats treated with IMD showed that organs were normal in size and appearance. The control group showed normal architecture for the central vein, parenchyma,

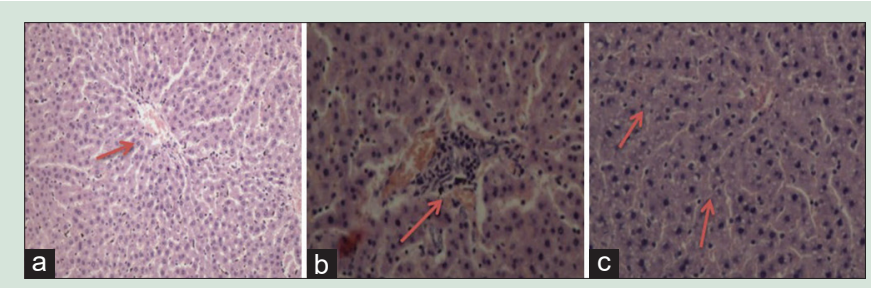

Figure 2: Effect of MB on the liver: The control rats (a) showed normal architecture for the central vein, parenchyma, and sinusoid (Red arrow) (H and E stain). Rats treated with TED (b) moderate portal inflammation and inflammatory cell hyperplasia in the portal area (Red arrow) (H and E stain). At the highest dose, (c) rats showed microvesicular steatosis and fatty changes (small arrow) together with congestion in sinusoids (large arrow) ( $\mathrm{H}$ and E stain). MB: Majun Brahmi; TED: Therapeutic effective dose 
MONIKA KUMARI, et al.: Toxicity Studies of Majun Brahmi and Itrifal Muqawwi Dimagh

Table 3: Hematological parameters in rats treated with Majun Brahmi for subchronic toxicity studies

\begin{tabular}{|c|c|c|c|c|c|c|c|c|}
\hline \multirow[t]{2}{*}{ Parameters } & \multicolumn{4}{|c|}{ Male rats ( $n=5$ per group) } & \multicolumn{4}{|c|}{ Female rats ( $n=5$ per group) } \\
\hline & $\begin{array}{l}\text { Control } \\
\text { (Saline) }\end{array}$ & $\begin{array}{c}\text { Group } 1 \\
(513.88 \\
\mathrm{mg} / \mathrm{kg} \text { bwt })\end{array}$ & $\begin{array}{c}\text { Group } 2 \\
\text { (1027.77 } \\
\mathrm{mg} / \mathrm{kg} \text { bwt) }\end{array}$ & $\begin{array}{c}\text { Group } 3 \\
\text { (2055.54 } \\
\mathrm{mg} / \mathrm{kg} \text { bwt) }\end{array}$ & $\begin{array}{l}\text { Control } \\
\text { (Saline) }\end{array}$ & $\begin{array}{c}\text { Group 1a } \\
(513.88 \\
\mathrm{mg} / \mathrm{kg} \text { bwt })\end{array}$ & $\begin{array}{l}\text { Group 2a } \\
\text { (1027.77 } \\
\mathrm{mg} / \mathrm{kg} \text { bwt) }\end{array}$ & $\begin{array}{c}\text { Group 3a } \\
\text { (2055.54 } \\
\mathrm{mg} / \mathrm{kg} \text { bwt) }\end{array}$ \\
\hline Hemoglobin (g/dL) & $14.4 \pm 1.37$ & $15.28 \pm 1.013$ & $15.9 \pm 0.62$ & $15.48 \pm 1.05$ & $15 \pm 0.93$ & $16 \pm 0.87$ & $16.14 \pm 1.29$ & $15.14 \pm 0.67$ \\
\hline $\begin{array}{l}\text { Lymphocyte } \\
\text { (percentage of TLC) }\end{array}$ & $78.34 \pm 12.60$ & $88.22 \pm 1.31$ & $91.575 \pm 3.47$ & $83.76 \pm 8.53$ & $80.14 \pm 3.77$ & $80.98 \pm 5.78$ & $83.36 \pm 3.86$ & $79.88 \pm 5.33$ \\
\hline $\operatorname{TLC}\left(\mathrm{m} / \mathrm{mm}^{3}\right)$ & $13.64 \pm 3.86$ & $13.36 \pm 2.00$ & $16.06 \pm 3.36$ & $13.32 \pm 3.19$ & $8.64 \pm 0.84$ & $12.48 \pm 1.87$ & $14.74 \pm 3.13$ & $11.80 \pm 2.90$ \\
\hline $\mathrm{RBC}\left(\mathrm{m} / \mathrm{mm}^{3}\right)$ & $3.32 \pm 3.05$ & $9.83 \pm 0.87^{\star}$ & $10.60 \pm 0.24^{*}$ & $5.63 \pm 2.58$ & $8.35 \pm 0.55$ & $9.20 \pm 0.92$ & $8.82 \pm 0.68$ & $8.76 \pm 0.26$ \\
\hline $\operatorname{PLT}\left(\mathrm{m} / \mathrm{mm}^{3}\right)$ & $859.8 \pm 18.93$ & $788.8 \pm 16.12^{*}$ & $661.8 \pm 15.37^{*}$ & $712.2 \pm 15.85^{*}$ & $690.2 \pm 16.41$ & $752.6 \pm 14.84^{*}$ & $585.2 \pm 18.10^{*}$ & $458.2 \pm 15.32^{\star}$ \\
\hline
\end{tabular}

Rats were treated with MB for 90 days. Values are mean \pm SD ( $n=5$ per group) ${ }^{\star}$ Significantly different from respective control, $P<0.05$. RBC: Red blood cell; PLT: Platelet; TLC: Total leukocyte count

Table 4: Biochemical parameters in rats treated with Majun Brahmi for subchronic toxicity studies

\begin{tabular}{|c|c|c|c|c|c|c|c|c|}
\hline \multirow[t]{2}{*}{ Parameters } & \multicolumn{4}{|c|}{ Male rats ( $n=5$ per group) } & \multicolumn{4}{|c|}{ Female rats ( $n=5$ per group ) } \\
\hline & $\begin{array}{l}\text { Control } \\
\text { (Saline) }\end{array}$ & $\begin{array}{c}\text { Group } 1 \\
(513.88 \\
\mathrm{mg} / \mathrm{kg} \text { bwt) }\end{array}$ & $\begin{array}{c}\text { Group } 2 \\
\text { (1027.77 } \\
\mathrm{mg} / \mathrm{kg} \text { bwt })\end{array}$ & $\begin{array}{c}\text { Group } 3 \\
\text { (2055.54 } \\
\mathrm{mg} / \mathrm{kg} \text { bwt) }\end{array}$ & $\begin{array}{l}\text { Control } \\
\text { (Saline) }\end{array}$ & $\begin{array}{c}\text { Group 1a } \\
(513.88 \\
\mathrm{mg} / \mathrm{kg} \mathrm{bwt})\end{array}$ & $\begin{array}{l}\text { Group 2a } \\
(1027.77 \\
\mathrm{mg} / \mathrm{kg} \text { bwt })\end{array}$ & $\begin{array}{c}\text { Group 3a } \\
(2055.54 \\
\mathrm{mg} / \mathrm{kg} \mathrm{bwt})\end{array}$ \\
\hline Urea $(\mathrm{mg} / \mathrm{dL})$ & $48.8 \pm 5.72$ & $41.8 \pm 6.98$ & $40.2 \pm 3.42$ & $49 \pm 10.49$ & $47.4 \pm 8.20$ & $48.6 \pm 5.32$ & $43.6 \pm 5.55$ & $52.4 \pm 6.35$ \\
\hline Creatinine (mg/dL) & $0.74 \pm 0.11$ & $0.60 \pm 0.12$ & $0.52 \pm 0.04$ & $0.70 \pm 0.07$ & $0.68 \pm 0.11$ & $0.62 \pm 0.08$ & $0.58 \pm 0.08$ & $0.58 \pm 0.04$ \\
\hline SGOT (IU/L) & $202.8 \pm 28.05$ & $151.8 \pm 15.7$ & $140.4 \pm 28.51$ & $165.4 \pm 8.79$ & $161.2 \pm 54.68$ & $140.2 \pm 13.08$ & $133.2 \pm 11.48$ & $127.2 \pm 29.74$ \\
\hline SGPT (IU/L) & $44.8 \pm 6.34$ & $53 \pm 17.56$ & $41.4 \pm 2.88$ & $59.2 \pm 8.53^{*}$ & $44.6 \pm 9.07$ & $41.2 \pm 4.49$ & $38.6 \pm 6.73$ & $39.2 \pm 9.28$ \\
\hline $\operatorname{ALP}(\mathrm{IU} / \mathrm{L})$ & $104 \pm 12.59$ & $101.8 \pm 7.69$ & $99.60 \pm 9.76$ & $111.6 \pm 7.82$ & $80.8 \pm 30.65$ & $128 \pm 36.11^{*}$ & $74.2 \pm 13.81$ & $76 \pm 10.70$ \\
\hline Bilirubin (Direct) (mg/dL) & $0.2 \pm 0.07$ & $0.16 \pm 0.05$ & $0.12 \pm 0.04$ & $0.12 \pm 0.04$ & $0.2 \pm 0.07$ & $0.16 \pm 0.09$ & $0.06 \pm 0.05$ & $0.16 \pm 0.05$ \\
\hline Bilirubin (Total) (mg/dL) & $0.8 \pm 0.07$ & $0.6 \pm 0.19$ & $0.54 \pm 0.13$ & $0.64 \pm 0.15$ & $0.74 \pm 0.15$ & $0.58 \pm 0.19$ & $0.52 \pm 0.08$ & $0.66 \pm 0.05$ \\
\hline Chol (mg/dL) & $30.6 \pm 7.86$ & $31.8 \pm 2.28$ & $30.8 \pm 5.50$ & $33 \pm 3.67$ & $29.6 \pm 4.67$ & $32.8 \pm 13.48$ & $27.4 \pm 7.40$ & $38.2 \pm 7.43$ \\
\hline $\mathrm{HDL}(\mathrm{mg} / \mathrm{dL})$ & $19 \pm 2.45$ & $21 \pm 1.41$ & $24.40 \pm 1.67$ & $20.60 \pm 1.94$ & $25.4 \pm 1.52$ & $28.2 \pm 3.11$ & $22.8 \pm 4.15$ & $25 \pm 5.43$ \\
\hline
\end{tabular}

Rats were treated with Majun Brahmi for 90 days. Values are mean \pm SD ( $n=5$ per group). ${ }^{\star}$ Significantly different from respective control, $P<0.05$. SGOT: Serum glutamic oxaloacetic transaminase; SGPT: Serum glutamic pyruvic transaminase; ALP: Alkaline phosphatase; HDL: High-density lipoprotein; SD: Standard deviation

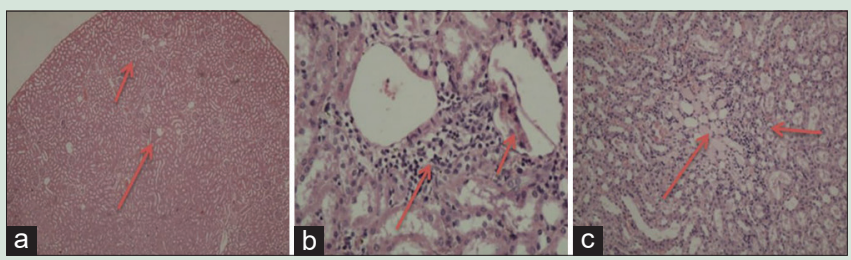

Figure 3: Effect of MB on the kidney: The control rats (a) showed norma glomeruli (small arrow) and normal tubules (large arrow) (H and E stain). Rats treated with TED (b) of MB showed tubular dilation (small arrow) and interstitial inflammation (large arrow) ( $\mathrm{H}$ and $\mathrm{E}$ stain). At the highest dose of $\mathrm{MB}$, (c) rats showed tubular atrophy with tubular cast (large arrow) and focal area of inflammation (large arrow) (H and E stain). MB: Majun Brahmi; TED: Therapeutic effective dose

and sinusoid in the liver. TED-treated rats showed mild congestion and mild fatty changes in the periportal area and in mid-zone. At the highest dose, sinusoid dilation, mild Kupffer cell hyperplasia, and lytic necrosis [Figure 6] were observed. The kidney of control rats showed normal tubules. Rats treated with TED showed increased cellularity in glomeruli and protein cast in tubules. At the highest dose, rats showed protein cast in tubules glomerular nephritis [Figure 7]. Normal white and red pulp area was observed in the splenic tissue of control rats. However, rats treated with TED showed mild congestion in the red pulp. At the highest dose of IMD-treated rats, mega karocytes in the red pulp and immature erythroid element in the red pulp [Figure 8] were observed.

\section{DISCUSSION}

The WHO has stipulated that nearly $70 \%-80 \%$ of the world's population relies on alternative medicines mostly of herbal sources for their

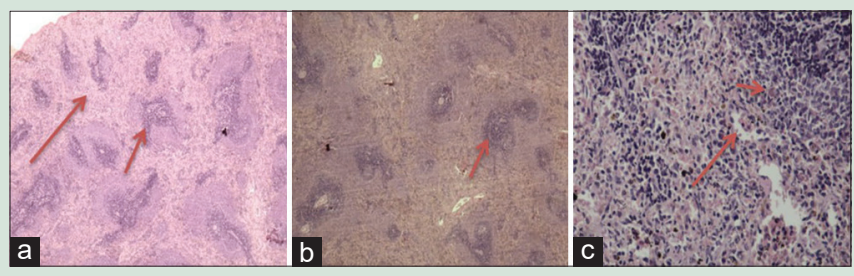

Figure 4: Effect of MB on the spleen: Control rats (a) showed normal white pulp (small arrow) and normal red pulp area of the spleen (large arrow) ( $\mathrm{H}$ and E stain). Rats treated with TED (b); $\mathrm{H}$ and $\mathrm{E}$ stain) showed mild congestion in the red pulp ( $\mathrm{H}$ and $\mathrm{E}$ stain). At the highest dose (c) of $M B$, rats showed megakaryocytes in red pulp (large arrow) and immature erythroid element in red pulp (small arrow) ( $\mathrm{H}$ and $\mathrm{E}$ stain). MB: Majun Brahmi; TED: Therapeutic effective dose primary health care, ${ }^{[20]}$ especially in developing and/or developed countries where conventional or modern drugs are majorly used. ${ }^{[21]}$ In India, herbal products are regularly used in traditional medicine such as Ayurveda and Unani which strengthen the body defenses without causing much side effects. The development of the new plant-based Unani formulations continues to have scientific, social, and commercial significance and appears to be gathering momentum in health relevant areas. MB and IMD are widely used in Unani system of medicine as a brain tonic for enhancing memory and cognitive functions. Despite their popularity and wide usage, there is no scientific documentation regarding the safety, quality, toxicity (if any), and efficacy of these two drugs in memory enhancement and improvement of cognitive function and neuroprotection.

A number of approaches are usually adopted to evaluate the safety of herbal drugs, using animal models. In the present study, acute and 
MONIKA KUMARI, et al.: Toxicity Studies of Majun Brahmi and Itrifal Muqawwi Dimagh

Table 5: Hematological parameters in rats treated with Itrifal Muqawwi Dimagh for subchronic toxicity studies

\begin{tabular}{|c|c|c|c|c|c|c|c|c|}
\hline \multirow[t]{2}{*}{ Parameters } & \multicolumn{4}{|c|}{ Male rats ( $n=5$ per group) } & \multicolumn{4}{|c|}{ Female rats ( $n=5$ per group) } \\
\hline & $\begin{array}{l}\text { Control } \\
\text { (Saline) }\end{array}$ & $\begin{array}{c}\text { Group } 1 \\
(513.88 \\
\mathrm{mg} / \mathrm{kg} \text { bwt })\end{array}$ & $\begin{array}{c}\text { Group } 2 \\
\text { (1027.77 } \\
\text { mg/kg bwt) }\end{array}$ & $\begin{array}{c}\text { Group } 3 \\
(2055.54 \\
\mathrm{mg} / \mathrm{kg} \text { bwt) }\end{array}$ & $\begin{array}{l}\text { Control } \\
\text { (Saline) }\end{array}$ & $\begin{array}{c}\text { Group 1a } \\
(513.88 \\
\mathrm{mg} / \mathrm{kg} \text { bwt })\end{array}$ & $\begin{array}{l}\text { Group 2a } \\
\text { (1027.77 } \\
\text { mg/kg bwt) }\end{array}$ & $\begin{array}{c}\text { Group 3a } \\
\text { (2055.54 } \\
\mathrm{mg} / \mathrm{kg} \text { bwt) }\end{array}$ \\
\hline Hemoglobin (g/dl) & $16.68 \pm 1.10$ & $15.66 \pm 0.56$ & $13.56 \pm 4.82$ & $16.86 \pm 0.43$ & $16.18 \pm 0.72$ & $16.20 \pm 0.84$ & $15.14 \pm 2.59$ & $15.82 \pm 1.00$ \\
\hline $\begin{array}{l}\text { Lymphocyte } \\
\text { (percentage of TLC) }\end{array}$ & $74.28 \pm 1.46$ & $70.40 \pm 1.14$ & $72.80 \pm 1.83$ & $79.64 \pm 3.93$ & $78.88 \pm 2.79$ & $86.54 \pm 0.81$ & $87.62 \pm 1.88$ & $86.82 \pm 2.28^{*}$ \\
\hline $\operatorname{TLC}\left(\mathrm{m} / \mathrm{mm}^{3}\right)$ & $15.48 \pm 3.19$ & $15.40 \pm 1.82$ & $10.16 \pm 4.25$ & $14.20 \pm 2.42$ & $11.18 \pm 3.22$ & $10.92 \pm 3.14$ & $12.14 \pm 3.99$ & $10.70 \pm 1.55$ \\
\hline $\mathrm{RBC}\left(\mathrm{m} / \mathrm{mm}^{3}\right)$ & $8.53 \pm 0.79$ & $7.54 \pm 0.71$ & $6.92 \pm 2.47$ & $8.50 \pm 0.21$ & $7.72 \pm 0.32$ & $7.79 \pm 0.55$ & $7.10 \pm 1.17$ & $7.38 \pm 0.583$ \\
\hline $\operatorname{PLT}\left(\mathrm{m} / \mathrm{mm}^{3}\right)$ & $718.2 \pm 14.53$ & $744.0 \pm 15.17$ & $645.8 \pm 15.97$ & $650.4 \pm 16.0$ & $452.2 \pm 14.82$ & $662.8 \pm 17.71$ & $583.6 \pm 14.40$ & $569.4 \pm 18.32$ \\
\hline
\end{tabular}

Rats were treated with Itrifal Muqawwi Dimagh for 90 days. Values are mean \pm SD ( $n=5$ per group). ${ }^{\star}$ Significantly different from respective control, $P<0.05$. RBC: Red blood cell; PLT: Platelet; TLC: Total leukocyte count; SD: Standard deviation

Table 6: Biochemical parameters in rats treated with Itrifal Muqawwi Dimagh for subchronic toxicity studies

\begin{tabular}{|c|c|c|c|c|c|c|c|c|}
\hline \multirow[t]{2}{*}{ Parameters } & \multicolumn{4}{|c|}{ Male rats ( $n=5$ per group) } & \multicolumn{4}{|c|}{ Female rats ( $n=5$ per group) } \\
\hline & $\begin{array}{l}\text { Control } \\
\text { (Saline) }\end{array}$ & $\begin{array}{c}\text { Group } 1 \\
\text { (513.88 } \\
\mathrm{mg} / \mathrm{kg} \text { bwt) }\end{array}$ & $\begin{array}{c}\text { Group } 2 \\
\text { (1027.77 } \\
\mathrm{mg} / \mathrm{kg} \text { bwt) }\end{array}$ & $\begin{array}{c}\text { Group } 3 \\
\text { (2055.54 } \\
\mathrm{mg} / \mathrm{kg} \text { bwt) }\end{array}$ & $\begin{array}{l}\text { Control } \\
\text { (Saline) }\end{array}$ & $\begin{array}{c}\text { Group 1a } \\
\text { (513.88 } \\
\mathrm{mg} / \mathrm{kg} \text { bwt) }\end{array}$ & $\begin{array}{l}\text { Group 2a } \\
\text { (1027.77 } \\
\mathrm{mg} / \mathrm{kg} \text { bwt) }\end{array}$ & $\begin{array}{c}\text { Group 3a } \\
\text { (2055.54 } \\
\mathrm{mg} / \mathrm{kg} \text { bwt) }\end{array}$ \\
\hline Urea (mg/dl) & $33.40 \pm 4.33$ & $36.80 \pm 3.70$ & $36.60 \pm 3.91$ & $33.80 \pm 4.08$ & $57.80 \pm 24.28$ & $32.40 \pm 3.57$ & $33.80 \pm 3.76$ & $40.80 \pm 3.70$ \\
\hline Creatinine (mg/dl) & $0.52 \pm 0.04$ & $0.46 \pm 0.11$ & $0.58 \pm 0.04$ & $0.52 \pm 0.04$ & $0.68 \pm 0.04$ & $0.68 \pm 0.08$ & $0.70 \pm 0.14$ & $0.68 \pm 0.14$ \\
\hline SGOT (IU/l) & $158.8 \pm 15.04$ & $150.8 \pm 9.52$ & $158.8 \pm 13.85$ & $155.4 \pm 15.11$ & $172.6 \pm 18.19$ & $177.6 \pm 5.94$ & $151.8 \pm 11.17$ & $162.8 \pm 12.79$ \\
\hline SGPT (IU/l) & $92.20 \pm 9.57$ & $73.00 \pm 7.10$ & $60.00 \pm 6.78$ & $53.60 \pm 6.95$ & $44.80 \pm 10.31$ & $40.00 \pm 1.58$ & $40.40 \pm 1.14$ & $44.40 \pm 2.88$ \\
\hline ALP (IU/l) & $166.4 \pm 15.47$ & $164.8 \pm 9.44$ & $101.4 \pm 15.39$ & $114.0 \pm 13.38$ & $159.6 \pm 19.97$ & $88.20 \pm 15.64$ & $72.80 \pm 12.87$ & $62.60 \pm 13.72$ \\
\hline Bilirubin (direct) (mg/dl) & $0.11 \pm 0.01$ & $0.10 \pm 0.01$ & $0.10 \pm 0.01$ & $0.12 \pm 0.04$ & $0.70 \pm 1.00$ & $0.14 \pm 0.05$ & $0.18 \pm 0.13$ & $0.20 \pm 0.07$ \\
\hline Bilirubin (total) (mg/dl) & $0.46 \pm 0.05$ & $0.50 \pm 0.07$ & $0.46 \pm 0.08$ & $0.54 \pm 0.11$ & $0.56 \pm 0.05$ & $0.48 \pm 0.08$ & $0.48 \pm 0.19$ & $0.64 \pm 0.08$ \\
\hline Chol (mg/dL) & $34.60 \pm 3.50$ & $28.40 \pm 2.70$ & $34.80 \pm 3.63$ & $28.40 \pm 4.98$ & $32.80 \pm 5.26$ & $27.40 \pm 3.05$ & $43.60 \pm 14.81$ & $25.60 \pm 3.36$ \\
\hline $\mathrm{HDL}(\mathrm{mg} / \mathrm{dL})$ & $21.00 \pm 1.87$ & $18.60 \pm 1.14$ & $21.20 \pm 1.78$ & $19.00 \pm 1.22$ & $24.20 \pm 6.61$ & $23.40 \pm 2.07$ & $26.20 \pm 2.38$ & $21.90 \pm 3.61$ \\
\hline
\end{tabular}

Rats were treated with Itrifal Muqawwi Dimagh for 90 days. Values are mean $\pm \mathrm{SD}\left(n=5\right.$ per group). ${ }^{\star}$ Significantly different from respective control, $P<0.05$. SGOT: Serum glutamic oxaloacetic transaminase; SGPT: Serum glutamic pyruvic transaminase; ALP: Alkaline phosphatase; HDL: High-density lipoprotein; SD: Standard deviation

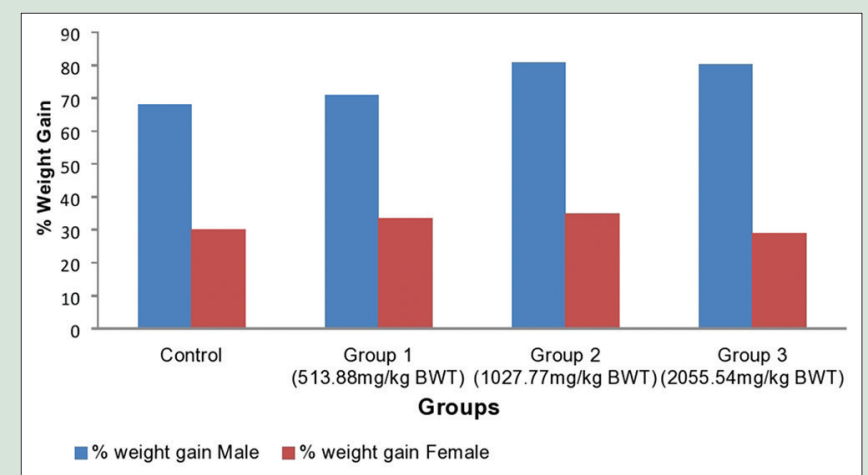

Figure 5: Body weight gain as a percentage in the control and IMD treated rats (sub chronic toxicity study). IMD: Itrifal Muqawwi Dimagh; BWT: body weight

subchronic toxicity studies were evaluated on MB and IMD in male and female rats.

No overt toxicity or mortality was found in any of the control or drug-treated animals, both in acute studies (14 days) and throughout the study duration of 90 days (subchronic study). Both food and water consumption remained unaffected during the study. Since bwt change is a direct and sensitive indicator of toxicity after exposure to potentially toxic substances, ${ }^{[22,23]}$ the pattern of bwt changes in the drug treated groups was not significantly different from the control group except in female rats treated with the highest dose, i.e., $2 \times$ TED. The observed changes indicate that the drugs under the study are not toxic; it can hence be inferred that these drugs neither do not produce any drastic tissue destruction nor interfere with nutrient absorption [Figures 1 and 5].

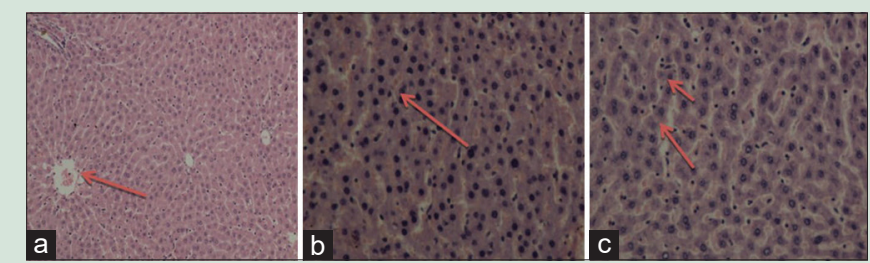

Figure 6: Effect of IMD on the liver: The control rats (a) showed normal architecture for the central vein, parenchyma, and sinusoid (Red arrow) ( $\mathrm{H}$ and E stain). Rats treated with TED (b) showed mild congestion and mild fatty changes in the periportal area and mid-zone (Red arrow) ( $\mathrm{H}$ and $\mathrm{E}$ stain). At the highest dose (c) rats showed sinusoids dilatation, mild Kupffer cell hyperplasia (large arrow), and lytic necrosis (small arrow) ( $\mathrm{H}$ and $\mathrm{E}$ stain). IMD: Itrifal Muqawwi Dimagh; TED: Therapeutic effective dose

An important target of several xenobiotics and drugs is the hemopoietic system $^{[24]}$ and is an indicator of anamolies in the body metabolic processes including response to injury, deprivation, and stress. ${ }^{[25]}$ Treatment with MB and IMD did not produce any significant difference in $\mathrm{Hb}$ content, lymphocytes, and TLC [Tables 3 and 5] in all the treated groups, indicating that these drugs do not affect erythrogenesis. The increased $\mathrm{RBC}$ in male rats treated with $\mathrm{MB}$ at low dose and TED may be the result of an increase in the blood cells or their production due to the treatment. Although the PLT count was decreased in all the treated groups, it was still within the physiologically normal range for rats. ${ }^{[26]}$

The liver is a vital organ involved in the metabolism and excretion of various drugs and xenobiotics which makes it highly susceptible to their adverse and toxic effects. Certain biomarkers like ALT, ALP, AST and bilirubin are indicators of liver injury. Similarly, the kidney also 


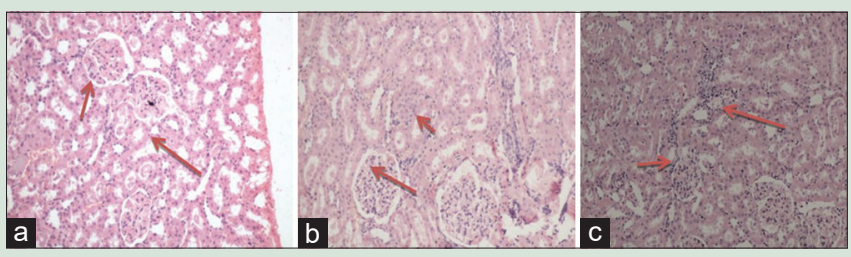

Figure 7: Effect of IMD on the kidney: The control rats (a) showed normal glomeruli (small arrow) and normal tubules (large arrow) (H and E stain). Rats treated with TED (b) $\mathrm{H}$ and $\mathrm{E}$ stain) showed increased cellularity in glomeruli (large red arrow), protein cast in tubules (small red arrow) ( $\mathrm{H}$ and $\mathrm{E}$ stain). At the highest dose of IMD (c) rats showed protein cast in tubules (large arrow) and glomerular nephritis (small arrow) (H and E stain). IMD: Itrifal Muqawwi Dimagh; TED: Therapeutic effective dose

plays a vital role in drug excretion and hence is a major organ that can evoke drug related toxic responses and serves as an important target for toxicological studies. ${ }^{[25]}$ Serum ALT, AST, urea and creatinine can reflect liver and kidney functions; and are markers of liver and kidney damage. ${ }^{[27,28]}$

No statistically significant changes were observed in all the biochemical parameters in rats of both sexes treated with different doses of $\mathrm{MB}$ and IMD. This clearly suggests that acute as well as subchronic, repeated administration of these Unani drugs does not have any toxic effects on the liver and kidney.

Histological examination of all organs did not show any gross morphological changes in the drug-treated rats. Treatment with both $\mathrm{MB}$ and IMD resulted in little degenerative changes at the low dose and TED.

Histopathological examination of the spleen revealed extramedullary hematopoiesis in the red pulp of the spleen and chronic interstitial inflammation in the kidney at the $2 \times$ TED. Minimal and variable changes were observed in the liver, kidney, and spleen at the low dose and TED, while mild damage to all three organs was more pronounced at $2 \times$ TED. From the results, it can be inferred that in spite of such a long treatment schedule, no serious toxic effects were observed, especially at the clinically advocated dose of both MB and IMD.

\section{CONCLUSION}

In the present study, no toxicity signs were observed with respect to hematological, biochemical parameters as well as organ weight, gross, and histological examination, at the TED. Our investigations confirm the safety of these classical polyherbal formulations and provide scientific evidence for their long history of clinical use in the Unani system of medicine. Further studies on the effect of these formulations on cognitive function and neuroprotection are in progress in our laboratory.

\section{Acknowledgements}

The authors are thankful to the Central Council for Research in Unani Medicine, Department of AYUSH, Ministry of Health and Family Welfare (Government of India), for providing financial support for this study (Letter. No.-Z-28015/250/2015-HPC [EMR]-AYUSH-B).

\section{Financial support and sponsorship}

Central Council for Research in Unani Medicine (CCRUM), Department of AYUSH, Ministry of Health and Family Welfare (Government of India), provided financial support for this study, Letter. No. -Z-28015/250/2015-HPC (EMR) - AYUSH-B.

\section{Conflicts of interest}

There are no conflicts of interest.

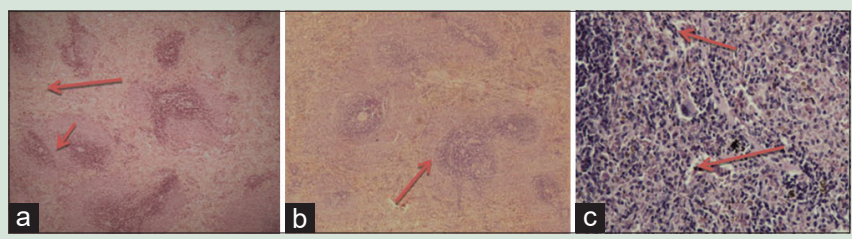

Figure 8: Effect of IMD on the spleen: Control rats (a) showed normal white pulp (small arrow) and normal red pulp area of the spleen (large arrow) ( $\mathrm{H}$ and $\mathrm{E}$ stain). Rats treated with TED (b) showed mild congestion in the red pulp ( $\mathrm{H}$ and $\mathrm{E}$ stain). At the highest dose (c) of IMD, rats showed megakaryocytes in the red pulp (large arrow) and immature erythroid element in the red pulp (small arrow) (H and E stain). IMD: Itrifal Muqawwi Dimagh; TED: Therapeutic effective dose

\section{REFERENCES}

1. Razzack MA. Holistic concepts in Unani medicine. Hippocratic J Unani Med 2006;1:17-20.

2. Wal P, Wal A, Gupta S, Sharma G, Rai A. Pharmacovigilance of herbal products in India. J Young Pharm 2011;3:256-8.

3. Dar SA, Ghazanfar K, Akbar S, Masood A, Nazir T, Siddiqui KM, et al. Acute and Sub-acute oral toxicity studies of Deedan-A Unani drug in Albino rats. J Appl Pharm Sci 2015;5:107-14.

4. Husain I, Akhtar M, Shaharyar M, Islamuddin M, Abdin MZ, Akhtar MJ, et al. High-salt- and cholesterol diet-associated cognitive impairment attenuated by tannins-enriched fraction of Emblica officinalis via inhibiting NF-kB pathway. Inflammopharmacology 2018;26:147-56

5. Piyabhan P Wetchateng T. Bacopa monnieri (Brahmi) prevents cognitive deficit by maintaining CA2/3 VGLUT1 density of sub-chronic phencyclidine rat model of schizophrenia in normal level. J Med Assoc Thai 2016;99 Suppl 4:S222-9.

6. Tang EL, Rajarajeswaran J, Fung SY, Kanthimathi MS. Antioxidant activity of Coriandrum sativum and protection against DNA damage and cancer cell migration. BMC Complement Altern Med 2013;13:347.

7. Jain S, Sangma T, Shukla SK, Mediratta PK. Effect of Cinnamomum zeylanicum extract on scopolamine-induced cognitive impairment and oxidative stress in rats. Nutr Neurosci 2015;18:210-6.

8. Batool Z, Sadir S, Liaquat L, Tabassum S, Madiha S, Rafiq S, et al. Repeated administration of almonds increases brain acetylcholine levels and enhances memory function in healthy rats while attenuates memory deficits in animal model of amnesia. Brain Res Bull 2016;120:63-74.

9. Government of India and Ministry of Health and Family Welfare (Deptartment of AYUSH). National Formulary of Unani Medicine. Vol. 1. Government of India and Ministry of Health and Family Welfare (Department of AYUSH); 2008. p. 70, 89.

10. Reagan-Shaw S, Nihal M, Ahmad N. Dose translation from animal to human studies revisited. FASEB J 2008;22:659-61.

11. Drabkin DL, Austin JH. Spectrophotometric studies I. Spectrophotometric constants for common hemoglobin derivatives in human, dog, and rabbit blood. J Biol Chem 1932;98:719-33.

12. Slot C. Plasma creatinine determination. A new and specific Jaffe reaction method. Scand J Clin Lab Invest 1965;17:381-7.

13. Fawcett JK, Scott JE. A rapid and precise method for the determination of urea. J Clin Pathol 1960;13:156-9.

14. Tietz NW. Textbook of Clinical Chemistry. Philadelphia, PA: Saunders; 1986.

15. Doumas BT, Biggs HG, Arends RL, Pinto PV. Determination of serum albumin. In: Standard Methods of Clinical Chemistry. Vol. 7: Elsevier Philadelphia, PA, USA; 1972. p. 175-88.

16. Jendrassik L, Grof P. Colorimetric method of determination of bilirubin. Biochem Z 1938;297:81-2.

17. Bradley DW, Maynard JE, Emery G, Webster H. Transaminase activities in serum of long-term hemodialysis patients. Clin Chem 1972;18:1442.

18. Wilkinson JH, Boutwell JH, Winsten S. Evaluation of a new system for the kinetic measurement of serum alkaline phosphatase. Clin Chem 1969;15:487-95.

19. Allain CC, Poon LS, Chan CS, Richmond W, Fu PC. Enzymatic determination of total serum cholesterol. Clin Chem 1974;20:470-5

20. Hariharan S, Suba V, Murugesan M. Toxicological assessment of Siddha herbomineral preparation KASHA Gulanthaga Mathirai in animal models. Int J Pharma Bio Sci 2012;4:646-56.

21. Ogbonnia S, Adekunle AA, Bosa MK, Enwuru VN. Evaluation of acute and subacute toxicity of Alstoniacongensis Engler (Apocynaceae) bark and Xylopia aethiopica (Dunal) A. rich (Annonaceae) fruit mixtures used in the treatment of diabetes. Afr J Biotechnol 2008;7:701-5. 
22. Teo S, Stirling D, Thomas S, Hoberman A, Kiorpes A, Khetani V. A 90-day oral gavage toxicity study of D-methylphenidate and D, L-methylphenidate in Sprague-Dawley rats. Toxicology 2002;179:183-96.

23. Raza M, Al-Shabanah OA, El-Hadiyah TM, Al-Majed AA. Effect of prolonged vigabatrin treatment on hematological and biochemical parameters in plasma, liver and kidney of Swiss albino mice. Sci Pharm 2002;70:135-45.

24. Gribaldo L. Haematotoxicology: Scientific basic and regulatory aspects. Altern Lab Anim 2002;30:111-14.

25. Dar SA, Akbar S, Ghazanfar K, Hamdani M, Nazir T, Masood A, et al. Sub-chronic oral toxicity study of Kushta Qalai (a unique herbo-mineral Unani formulation) in Wistar Rats. Br Biomed Bull 2016;4:103-21.

26. Ringler DH, Dabich L. Hematology and Clinical Biochemistry. The Laboratory Rat. Vol. 1. London: Academic Press; 1979. p. 105-18.

27. Ozer J, Ratner M, Shaw M, Bailey W, Schomaker S. The current state of serum biomarkers of hepatotoxicity. Toxicology 2008;245:194-205.

28. Fuchs TC, Frick K, Emde B, Czasch S, von Landenberg F, Hewitt P. Evaluation of novel acute urinary rat kidney toxicity biomarker for subacute toxicity studies in preclinical trials. Toxicol Pathol 2012;40:1031-48. 